\title{
Village-Owned Enterprises Management and Community Welfare in Tridadi Village Sleman Regency
}

\author{
Muhammad Iqbal ${ }^{1, *}$ and Helen Dian Fridayani ${ }^{1}$
}

\author{
${ }^{1}$ Department of Political Science, National Cheng Kung University, Tainan City, Taiwan \\ *Corresponding author. Email: u18097019@ncku.edu.tw
}

\begin{abstract}
Development in Indonesia, which was launched from the village, is considered to be very effective in supporting the development of national development in Indonesia. One of them is by establishing VillageOwned Enterprises, as a pillar of economic development in Village-Owned Enterprises is expected to make a very large contribution. For this reason, this research will discuss how Village-Owned Enterprises can affect the welfare of the community in Tridadi Village, Sleman Regency. This research uses quantitative research methods and the results of the analysis using SmartPLS. The results of this study indicate that there is an influence between the management of Village-Owned Enterprises Tridadi Makmur and the level of community welfare in Tridadi Village. Of the 4 (four) Village-Owned Enterprises management indicators that have been mentioned and managed above, 3 (three) of them influence the welfare of the community, while 1 (one) other does not influence the welfare of the community. Indicators that influence people's welfare are Economic or Financial Capital, Human Capital, and Social Capital. Meanwhile, the indicator that does not influence people's welfare is Natural Capital. The level of welfare in material terms achieved by the community is the ownership of adequate housing and the ability to buy clothing and food.
\end{abstract}

Keywords: Village-Owned Enterprises; Social Welfare; Rural Development

\section{INTRODUCTION}

Village Development is the basis of national development, because if each village has been able to carry out development independently then the prosperity of the community will be easily realized and nationally will increase the prosperity index of the Indonesian people [1].

National Development is an effort made to improve all aspects of the life of the community, the Nation, and the State [2]. The purpose of development is to build independence, including rural development. Most of the population of the Indonesian people themselves live in rural areas. Therefore, the central point of development is rural areas. According to [2], the village is a legal community unit that has an original structure based on special original rights. National development in general is oriented towards improving the social welfare of the community in the economic sector [3]. The village is the main center of economic development because the village is the initial sector of the State's economic activity.

Entering July 2019 at present, the number of VillageOwned Enterprises (BUMDes) throughout Indonesia reaches 35 thousand from 74,910 villages throughout the archipelago [2]. This data then becomes a reference for conducting research and research on the development of BUMDes in each village. Over time this becomes an attraction for exploring deeper in terms of development, productivity or even the impact on the welfare of village communities [4].
BUMDes is a pillar of economic activity in the village that functions as a social institution and a commercial institution. BUMDes as a social institution favors the interests of the community through its contribution in the provision of social services. Meanwhile, as a commercial institution, it aims to make a profit by offering local resources (goods and services) to the market. In running its business the principle of efficiency and effectiveness must always be emphasized [5]. BUMDes as a legal entity is formed based on the applicable laws and regulations, and in accordance with the agreements that are built in the village community.

In order to achieve the social welfare of the community, the central government made a new policy regarding the existence of Village-Owned Enterprises (BUMDes) that must exist in every village as an effort to help the community's small business units to be well managed (Berlian Ramadana \& Ribawanto, 1068). BUMDes is also present as an effort by the government to tackle community economic problems by mobilizing the management of village assets as well as assisting and supporting community small businesses in meeting their daily needs [6].

In its implementation, the running of a BUMDes must be balanced with the use of Natural Resources (SDA) and Human Resources (HR) in the village, to maximize the potential of the existing village [7]. By seeing the potential of the village based on its Natural Resources, the establishment of BUMDes will be right on target by knowing the geographical layout of the area and the ability of the village to manage its resources [8]. As an example of 
people in the mountains, they grow fruits and vegetables, which are the main livelihoods that can be packaged in good packaging or sold online at the market place, so it does not apply to coastal areas. The geographical location of an area determines what business a village will develop, because of different regional conditions that cannot be implemented in different regions [9].

Other factors in terms of HR/Human Resources also greatly influence the effectiveness of the BUMDes program, we can observe in terms of education that up to now the education of the people in the village is still very minimal when compared to the people living in the City [10]. People who live in the village need to be assisted in processing and distributing and there is a need for intensive guidance so that the program proposed can be realized properly [11].

The existence of a village-owned business entity in Triadi Village, Sleman is an effort by the regional government to strengthen the village economy. This is because the village-owned enterprise is one of the institutions engaged in the social and economic fields [9]. BUMDes Trdadi Makmur also acts as a service provider to rural communities specifically in the business sector. The establishment of BUMDes in the Triadi Village refers to the highest regulation in Law No. 6 of 2014 as stipulated in Article (87), which is about Village-Owned Enterprises [12]. The hope of BUMDes is that it can help in the income of the village. BUMDes Tridadi Makmur has one business unit engaged in tourism, namely the construction of the tourist attraction "Puri Mataram".

However, the contribution made by the business entity owned by the village of Tridadi Makmur, which is currently underway, is still not optimal. This becomes a great homework for the Head of Triadi Village in running the economy in the village, because if the Triadi Makmur BUMDes can maintain its existence then it will be more widely known and can make income for the village treasury, but on the other hand, if the program is run stalled and many people do not care about the existence of their businesses, the capital poured out by the Village will be Deficit [13]. So that it can be said that the existence of a village-owned enterprise is hoped to be not only a pseudo form or just a signboard but a sustainable business.

There are many types of businesses that can be done in a BUMDes including intermediaries, businesses in the social business sector, rental business, joint ventures, financial business, and contractors. Each of these businesses must be carried out in accordance with the place by looking at the condition of the village and the ability of the village to manage it. The implementation of the BUMDes program must also refer to the prevailing laws or regulations taking into account the agreement of the whole village community beforehand. Regarding BUMDes financial resources, it can come from the Village budget and income or even citizens contributions and also from private sector financiers depending on how the agreement was made in advance.

\section{RESEARCH METHODS}

The type of research used in this study is the type of quantitative approach. Quantitative research is a research method that uses the process of data in the form of numbers as a tool to analyze and conduct research studies, especially regarding what has been examined.

The population in this study was the population in Tridadi Village, Sleman Regency amounting to 14,728 people. To determine the sample to be used in this study, researchers used a probability sampling technique with a simple type of random sampling. To determine the number of samples, researchers refer to the Slovin formula. The number of samples in this study was 100 residents of Tridadi Village. Survey results were analyzed using the SmartPLS 3.0 application.

\section{RESULTS AND DISCUSSION}

\subsection{Testing the Outer Model}

Outer model testing is done by evaluating an outer model with its reflection indicator. There are 3 (three) criteria which are indicators of reflection, namely convergent validity, discriminant validity, and composite reliability. The following are outputs from loading factors that influence BUMDes on community welfare.

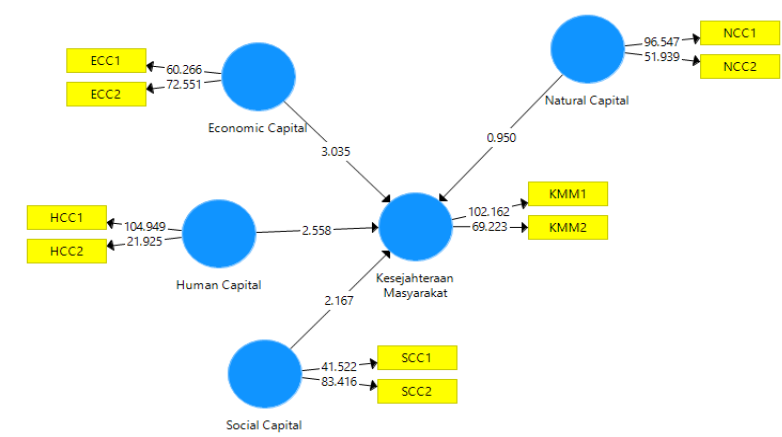

Figure 1. Loading factor

Fig. 1 is an output of the loading factor that will be used as a basis for measuring and knowing the results and interpretation of the outer loading effect of BUMDes on community welfare. In this model, there is an equation to measure outer loading as follows:

Public Welfare $=0.950$ Natural Capital $(\mathrm{NCC})+3,305$ Economic Capital $($ ECC) $+2,558$ Human Capital $(\mathrm{HCC})$ $+2,167$ Social Capital (SCC). Can also be written with the following equation: Public Welfare $=0,950 \mathrm{NCC}+$ $3,305 \mathrm{ECC}+2,558 \mathrm{HCC}+2,167 \mathrm{SCC}$.

The first criterion and the second criterion namely convergent validity and discriminant validity can be determined by looking at the results of the score of the outer model which is the Average Variance Extracted (AVE) value. The validity of data that can be known from 
AVE has a value limit for data if it is said to be valid. The AVE value is said to be valid if the AVE score exceeds 0.50 , if it is less than 0.05 then the data cannot be said to be valid.

Table 1. Convergent Validity and Discriminant Validity

\begin{tabular}{|l|l|l|l|}
\hline Variabel & Item & Loading factor & Ave \\
\hline \multirow{2}{*}{ Natural Capital } & NCC 1 & 96.547 & \multirow{2}{*}{0.891} \\
\cline { 2 - 3 } & NCC 2 & 51939 & \\
\hline \multirow{2}{*}{ Economic Capital } & ECC 1 & 60.266 & \multirow{2}{*}{0.891} \\
\cline { 2 - 3 } & ECC 2 & 72.551 & \\
\hline \multirow{2}{*}{ Human Capital } & HCC 1 & 104.959 & \multirow{2}{*}{0.806} \\
\cline { 2 - 3 } Social Capital & HCC 2 & 21.925 & \\
\hline \multirow{2}{*}{ Social Welfare } & SCC 1 & 41.522 & \multirow{2}{*}{0.849} \\
\cline { 2 - 3 } & SCC 2 & 83.416 & \\
\cline { 2 - 3 } & KMM 1 2 & 102.162 & 69.223 \\
\hline
\end{tabular}

Source: processed from primary data, 2019

In the Table 1 shows the results of the Convergent Validity and Discriminant Validity tests which use the values of loading factor and AVE. The results of the table above show that all statements with their respective research variables consisting of Natural Capital, Economic Capital, Human Capital, Social Capital, and Social Welfare have a loading factor exceeding 0.50 and also having a AVE that is more than 0.50. It can be concluded that all questions in all research variables are valid and meet convergent validity.

The third criterion, namely Composite Reliability or reliability testing was tested using 2 (two) criteria, namely composite reliability and Cronbach's alpha. A construct can be said to be reliable if the value of composite reliability and Cronbach's alpha exceeds 0.70. The composite reliability and cronbachs alpha outputs of BUMDes and Community Welfare are as follows:

Table 2. Composite Reliability and Cronbach's Alpha

\begin{tabular}{|c|c|c|}
\hline Variabel & $\begin{array}{c}\text { Composite } \\
\text { Reliability }\end{array}$ & $\begin{array}{c}\text { Cronbachs } \\
\text { Alpha }\end{array}$ \\
\hline Natural Capital & 0,942 & 0,877 \\
\hline Economic Capital & 0,942 & 0,878 \\
\hline Human Capital & 0,893 & 0,766 \\
\hline Social Capital & 0,918 & 0,825 \\
\hline Public welfare & 0,961 & 0,918 \\
\hline
\end{tabular}

Source: from premier sources, 2019

Based on the composite reliability and Cronbach's alpha output in Table 2 above, it shows that the Community Welfare variable has the highest composite reliability and Cronbach's alpha values than the other variables, which are 0.961 and 0.918 . While the lowest composite reliability and Cronbach's alpha are held by the Human Capital variable, which is 0.893 and 0.766 .

In addition, based on the composite output reliability and Cronbach's alpha shows that each of the constructs has exceeded and is above 0.70 . Thus, it can be concluded that each construct in the model above has good reliability.

\subsection{Testing the Inner Model}

Inner model testing is a test that aims to measure or see the relationship between the construct, the significance value and also the R-square of the research model. By using the value of $\mathrm{R}$-square for the dependent construct of the t-test as well as the significance of the coefficient of structural path parameters to take measurements of the structural model. The results of R-Square obtained through smartPLS will be shown in Table 3 below:

Table 3. Regression Results (R-Square)

\begin{tabular}{|c|c|}
\hline Variabel & R-Square \\
\hline Public welfare & 0,813 \\
\hline \multicolumn{2}{|c|}{ Source: processed from primary data, 2019}
\end{tabular}

Based on the data presented in Table 3 explains that the results of the R-Square between the management of BUMDes to the welfare of the community show a figure of 0.813 . Then it can be concluded that the influence of natural capital, economic capital, human capital, and social capital with the welfare of the community is $81.3 \%$.

\subsection{Hypothesis testing}

Hypothesis testing is testing the hypothesis between the dependent variable and the independent variable that tests using the $\mathrm{t}$ statistic or t-test. The $\mathrm{t}$ value is obtained from the $t$ table, where a test can be said to be significant if the T-statistic value is greater than (>) 1.96 and the value of the P-value is smaller than $(<) 0.05$. To test the hypothesis we need to look at the output path coefficient of the bootstrap resampling results obtained through smartPLS. The data can be seen from the figure and table below:

Table 4. Hypothesis Testing

\begin{tabular}{|c|c|c|c|c|}
\hline Variabel & $\begin{array}{c}\text { Standard } \\
\text { Deviation } \\
(\text { STDEV) }\end{array}$ & $\begin{array}{c}\text { T Statistics } \\
(\mid \mathbf{O} / \text { STDEV } \mid)\end{array}$ & $\begin{array}{c}\text { P } \\
\text { Values }\end{array}$ & Result \\
\hline EC ->Public welfare & 0,149 & 3,035 & 0,003 & Received \\
\hline HC ->Public welfare & 0,143 & 2,558 & 0,011 & Received \\
\hline NC ->Public welfare & 0,105 & 0,950 & 0,342 & Rejected \\
\hline SC ->Public welfare & 0,112 & 2,167 & 0,031 & Received \\
\hline
\end{tabular}

Source: processed from primary data, 2019

Based on Table 4 the results of hypothesis testing show that the hypothesis received is economic capital, human capital, and social capital because the value of T-statistics> 1.96 and the value of P-values $<0.05$ which means to have significant influence. Whereas for natural capital hypothesis testing is rejected because the value of $\mathrm{T}$ statistics $<1.96$ and the value of P-values> of 0.05 which means it does not have a significant effect.

\section{a. Hypothesis 1 Test Results:}

The first hypothesis test in this study are:

Ha: economic capital affects the level of community welfare

Ho: economic capital does not affect the level of community welfare

Based on Table 4 shows that the results of the T-statistic is greater than the predetermined number value of 1.96 which 
is 3.035 and the value of $\mathrm{P}$ values is smaller than 0.05 which is a predetermined number that is 0.003 . Then it can be concluded that economic capital affects the level of community welfare so that the first hypothesis (H1) is accepted or proven (Ha is accepted and Ho is rejected).

\section{b. Hypothesis 2 Test Results:}

The second hypothesis test in this study are:

Ha: human capital affects the level of community welfare

Ho: Human capital does not affect the level of community welfare

Based on Table 4 shows that the T-statistic results are greater than the predetermined number value of 1.96 which is equal to 2.558 and the value of $P$ values less than 0.05 which is a predetermined number that is 0.011 . It can be concluded that human capital influences the level of community welfare so that the second hypothesis $(\mathrm{H} 2)$ is accepted or proven (Ha is accepted and Ho is rejected).

\section{c. Hypothesis 3 Test Results:}

The third hypothesis test in this study are:

Ha: natural capital affects the level of community welfare.

Ho: natural capital does not affect the level of community welfare.

Based on Table 4 shows that the T-statistic results are smaller than the predetermined number is 1.96 which is equal to 0.950 and the value of $P$ values is greater than 0.05 which is a predetermined number that is 0.342 . So it can be concluded that natural capital does not affect the level of community welfare so that the third hypothesis (H3) is rejected or not proven (Ha is rejected and Ho is accepted).

\section{d. Hypothesis 4 Test Results:}

The first hypothesis test in this study are:

Ha: social capital affects the level of community welfare

Ho: social capital does not affect the level of community welfare

Based on Table 4 shows that the results of the T-statistic are greater than the predetermined number is 1.96 which is equal to 2.167 and the value of $\mathrm{P}$ values is smaller than 0.05 which is a predetermined number that is 0.031 . Then it can be concluded that social capital affects the level of community welfare so that the second hypothesis $(\mathrm{H} 2)$ is accepted or proven (Ha) accepted and (Ho) is rejected.

\section{CONCLUSION}

The purpose of this research is to find out and analyze how the influence of the management of Village Owned Enterprises (BUMDes) on the level of community welfare in the Tridadi Makmur BUMDes case study located in Tridadi Village, Sleman District, Sleman Regency, Special Region of Yogyakarta in 2019. This research using the theory of management BUMDes owned by Trienekens, Vermelen and Hovens, as well as using welfare theory based on indicators from the Indonesian Central Bureau of Statistics.

This study focuses on how the influence of BUMDesTridadi Makmur based on 4 (four) indicators belonging to Trienekens, Vermelen and Hovens in managing BUMDes namely Natural Capital, Economic or Financial Capital, Human Capital, and Social Capital on the welfare of the community in Tridadi Village, which until now still running. Indicators of the level of community welfare in material terms are measured based on indicators from the Indonesian Central Statistics Agency which include the ownership of adequate housing and the ability to buy clothing and food. These indicators will be used to create questionnaire questions which will then be answered by respondents to be processed again and then analyzed.

The results of this study indicate that there is an influence between the management of BUMDesTridadi Makmur and the level of community welfare in Tridadi Village. Of the 4 (four) indicators of BUMDes management that have been mentioned and managed above, 3 (three) of them influence the welfare of the community, while 1 (one) other has no influence on the welfare of the community. Indicators that have an influence on people's welfare are Economic or Financial Capital, Human Capital, and Social Capital Meanwhile, the indicator that has no influence on people's welfare is Natural Capital. The level of welfare in material terms achieved by the community is the ownership of adequate housing and the ability to buy clothing and food.

\section{REFERENCES}

[1] Kusuma, G. H., \& Krisnadewara, P. D. Innovation Challenges of Village-owned Enterprises. 2019.

Kinerja, 23(1), 54-66.

[2] Suprapto, P. A., Sarja, N. L. A. K. Y., Suastika, I. N., \& Wongbuangam, B. Developing Rural Community Economies Through Village-Owned Enterprises in the Province of Bali. 2019. 354(iCASTSS), 398-404. https://doi.org/10.2991/icastss-19.2019.85

[3] Hasan, F., \& Yaya, R. Governance of Village Owned Enterprise from The Perspective of Reinventing Government. 2019. Riset Akuntansi Dan Keuangan Indonesia, 4(3), 146-155. https://doi.org/10.23917/reaksi.v4i3.9123

[4] Yusuf, E., Gunanto, A., Arianti, F., Hayati, B., \& Studies, D. Strategy for the Development of Coastal Village-Owned Enterprises (Bumdes) As a Form of Independent. 2019. International Journal of Mechanical Engineering and Technology, 10(06), 160-169

[5] Sumantra, K., Suryani, K., Widnyana, I. W., Carmen C, M., Sutrisna, I.. P., Oktarina, \& Dana, R. S. Swot Analysis of Village Owned Enterprises (Bumdes) Trading Business of "Ayu Bagia” Goods. 2019. International Journal of Sustainability, Education, and Global Creative Economic (IJSEGCE), 2(1), 15-20.

[6] Ariutama, I. G. A., Saputra, A. H., \& Sukmono, R. THE Role of Village-Owned Enterprises (Bumdes) to Rural Development: A Comparative Institutional 
Analysis. 2017. Jurnal Kajian Ekonomi Dan Keuangan Daerah, 2(1), 59-65.

[7] Lubis, A., Muda, I., \& Rustam. Analysis of Ownership and Stock Composition of Vocational Business Enterprises (BUMDES) and Its Impact on qOmsetq of Business Owned Enterprises. 2018. 1st Economics and Business International Conference, 46(Ebic 2017), 274-277. https://doi.org/10.2991/ebic17.2018 .43

[8] Srirejeki, K. Empowering the Role of Village Owned Enterprises (BUMDes) for Rural Development: Case of Indonesia. 2018. Journal of Accounting, Management, and Economics, 20(1), 5-10. Retrieved from

http://jos.unsoed.ac.id/index.php/jame/article/view/1018 1727

[9] Astut, S. J. W., \& Suaedi, F. Building Independent Villages through Collaborative Governance by VillageOwned Enterprises (Best Practice from Panggungharjo Village, Central Java, Indonesia) By. 2018. Procedia Computer Science, 2(1), 1-5. https://doi.org/10.15439/2019F121
[10] Sunada, I. K., \& Sandi, I. K. Business Development Independent Populist Economic Owned Enterprises as a Village. 2018. International Journal of Contemporary Research and Review, 9(06), 20792 20799. https://doi.org/10.15520/ijcrr/2018/9/06/520

[11] Winarsi, S., Widyantoro, A., Moechthar, O., \& Airlangga, U. The Law Principles for Village-Owned Enterprises (BUMDes) Management in Indonesia to Improve the Village's Economy. 2018. International Journal of Sociological Jurisprudence, 1(2), 130-136.

[12] Sari, Y. Measuring the Financial Performance of Village Owned Enterprises (VOEs). 2019. Journal of Public Administration Studies, 4(1), 14-18. https://doi.org/10.21776/ub.jpas.2019.004.01.3

[13] Sofyani, H., Atmaja, R., \& Rezki, S. B. Success Factors of Village-Owned Enterprises (BUMDes) Performance in Indonesia: An Exploratory Study. 2019. Journal of Accounting and Investment, 20(2). https://doi.org/10.18196/jai.2002116 